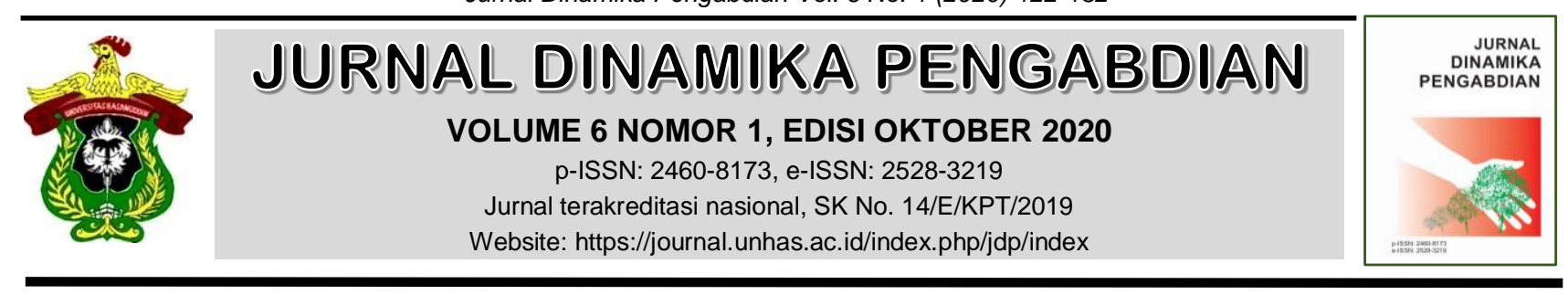

\title{
POTENSI POMPA HYDRAM (HYDRAULIC RAM PUMP) BERTEKNOLOGI HYDRO POWER TANPA LISTRIK DAN RAMAH LINGKUNGAN DI DESA NEPO KABUPATEN BARRU
}

\author{
Muh. Ikbal Putera*, Arman, dan Irmayani \\ *e-mail: lqbalputera1@gmail.com
}

Fakultas Pertanian, Peternakan dan Perikanan

Universitas Muhammadiyah Parepare

Diserahkan tanggal 27 September 2020, disetujui tanggal 8 Oktober 2020

\begin{abstract}
ABSTRAK
Masalah air termasuk masalah yang tidak mudah diperoleh terutama pada saat kondisi musim kemarau. Sejatinya air merupakan kebutuhan vital bagi kehidupan manusia, tumbuhan dan hewan. Air untuk kebutuhan manusia digunakan untuk komsumsi air minum, masak, mencuci dan mandi. Daerah dengan topografi relatif datar, air relatif mudah diperoleh dari sumber air sumur dan sungai-sungai yang mengalir yang relatif tidak dalam, sehingga untuk memperoleh sumber air relatif mudah. Pada areal pengabdian dengan kondisi topografi datar dan sedikit berbukit-bukit, sehingga petani untuk memperoleh air dalam aktifitas pertanian dan untuk kebutuhan hidup, air diperoleh dari sungai dan sumur galian, mata air dan sumur dalam (air tanah). Saat hujan, sumber air mudah diperoleh dari air sungai yang melimpah dan dari sumur galian yang memiliki tinggi air yang cukup. Permasalahan kebutuhan air bagi masyarakat desa yang tinggal di daerah berbukit dan bergunung adalah membutuhkan teknologi tepat guna Pompa Hydram yang relatif murah dan terjangkau oleh masyarakat karena memiliki daya penggerak tenaga air (Hydro Power), hemat energi dan ramah lingkungan. Kegiatan pengabdian, mengggunakan metode survei kegiatan aktifitas pemasangan dan pengamatan lapangan, Participatory Rural Appraisal (PRA) yaitu melibatkan masyarakat. Kegiatan ini dilaksanakan melalui: penyuluhan, pelatihan, dan demonstrasi. Manfaat yang diperoleh bahwa dengan penerapan teknologi tepat guna, dengan potensi pompa hydram berasal dari sumber tenaga air yang memiliki kecepatan, energi potensial dan energi kinetik yang memberi hantaman air (water hammer) pada pipa pemasukan dan tabung kompressi, sehingga menimbulkan tekanan yang besar untuk mengangkat air ketempat yang lebih tinggi.
\end{abstract}

Kata kunci: Pompa Hydram, Hydro Power, Ramah Lingkungan, Mata air, Water hammer.

\section{ABSTRACT}

Water problems include problems that are not easily obtained, especially during conditions or dry seasons. Indeed water is a vital requirement for human, plant and animal life. Water for human needs is used for drinking, cooking, washing and bathing water. Areas with relatively flat topography, water is relatively easy to obtain from well water sources and rivers that flow relatively not deep, so to obtain water sources is relatively easy. In the service area with flat topography and slightly hilly, so farmers to obtain water in agricultural activities and for daily needs, water is obtained from rivers and dug wells, springs and deep wells (ground water). 
When it rains, water sources are easily obtained from abundant river water and from dug wells that have sufficient water level. The problem of water needs for rural communities who live in hilly and mountainous areas is the need for appropriate technology Hydram Pumps which are relatively inexpensive and affordable by the community because they have the power of hydropower, are energy efficient and environmentally friendly. Community service activities, using the survey method of installation activities and field observations, Participatory Rural Appraisal (PRA), which involves the community. This activity is carried out through: counseling, training and demonstrations. The results and benefits obtained by the application of appropriate technology, with the potential for hydram pumps come from water power sources that have speed, potential energy and kinetic energy that gives water hammer to the inlet pipe and compressed tube, so that it causes a great pressure to lift water to a higher place.

Keywords: Hydram Pump, Hydro Power, Environment Friendly, Springs, Water hammer.

\section{PENDAHULUAN}

Dalam upaya menanggulangi masalah penyediaan air, baik untuk kehidupan maupun untuk kegiatan pertanian, peternakan dan perikanan khususnya di daerah pedesaan, maka penggunaan pompa hydram berdasarkan pada sistem gravitasi yang sangat sederhana, baik dalam pembuatannya dan juga dalam pemeliharaannya. Pompa Hydram bekerja berdasarkan sistem gravitasi, tanpa menggunakan bahan bakar atau energi dari luar. Pompa ini memanfaatkan tenaga aliran yang jatuh dari tempat suatu sumber dan sebagian dari air itu dipompakan ke tempat yang lebih tinggi (Panly, 2015).

Teknologi pompa hydram (Hydraulic Ram Pump) merupakan salah satu pompa air yang hemat energi dan ramah lingkungan. Pompa hydram merupakan teknologi tepat guna dalam bidang pemompaan dengan menggunakan tenaga momentum air (water hammer) untuk menaikkan air, sehingga pompa hydram salah satu pompa air yang tidak menggunakan BBM dan listrik. Pompa hydram bekerja tanpa menggunakan bahan bakar atau energi dari luar. Pompa ini memanfaatkan tenaga aliran yang jatuh dari tempat suatu sumber dan sebagian dari air itu dipompakan ke tempat yang lebih tinggi. Pada berbagai situasi, pompa hidrolik ram memiliki keuntungan dibandingkan penggunaan pompa jenis lainnya, yaitu tidak membutuhkan bahan bakar atau tambahan tenaga dari sumber lain, tidak membutuhkan pelumasan, bentuknya sederhana, biaya pembuatannya serta pemeliharaannya murah dan tidak membutuhkan keterampilan teknik tinggi untuk membuatnya. Pompa ini bekerja dalam dua puluh empat jam per hari (Utomo, 2015).

Menurut Direktorat Pengelolaan Air (2009), bahwa pompa hydram merupakan salah satu alternatif teknologi aplikasi untuk irigasi dan secara teoritis memiliki keunggulan ekonomis dan efektifitas. Pompa hydram sangat baik digunakan pada wilayah yang mempunyai ketinggian areal di atas sumber air yang sulit terjangkau dengan sistem aliran 
Muh. Ikbal Putera, Arman, dan Irmayani: Potensi Pompa Hydram (Hydraulic Ram Pump) Berteknologi Hydro Power Tanpa Listrik dan Ramah Lingkungan di Desa Nepo Kabupaten Barru.

konvensional atau menggunakan aliran secara gravitasi.

Pompa hydram merupakan suatu alat yang digunakan untuk menaikkan air dari tempat rendah ke tempat yang lebih tinggi secara otomatis dengan energi yang berasal dari air itu sendiri (hydro power) dengan sistem gravitasi. Alat ini sederhana dan efektif digunakan pada kondisi yang sesuai dengan syarat-syarat yang diperlukan untuk operasinya. Dalam kerjanya alat ini, tekanan dinamik air yang ditimbulkan memungkinkan air mengalir dari tinggi vertikal (head) yang rendah, ke tempat yang lebih tinggi. Penggunaan hydraulic ram pump tidak terbatas hanya pada penyediaan air untuk kebutuhan rumah tangga, tapi juga dapat digunakan untuk memenuhi kebutuhan air untuk pertanian, peternakan dan perikanan darat.

Di beberapa pedesaan di Jepang, alat ini telah banyak digunakan sebagai alat penyediaan air untuk kegiatan pertanian maupun untuk keperluan domestik. Dalam operasinya, alat ini mempunyai keuntungan dibandingkan dengan jenis pompa lainnya, antara lain; tidak membutuhkan sumber tenaga tambahan, biaya operasinya murah, tidak memerlukan pelumasan, hanya mempunyai dua bagian yang bergerak sehingga memperkecil terjadinya keausan, perawatannya sederhana dan dapat bekerja dengan efisien pada kondisi yang sesuai serta dapat dibuat dengan peralatan bengkel yang sederhana (Sularso, 2004).
Prinsip kerja pompa hydram adalah pemanfaatan sistem gravitasi, dimana akan menciptakan energi dari hantaman air yang menabrak faksi air lainnya untuk mendorong ke tempat yang lebih tinggi. Untuk mendapatkan energi potensial dari hantaman air diperlukan syarat utama yaitu harus ada terjunan air yang dialirkan melalui pipa dengan beda tinggi elevasi dengan pompa hydram minimal 1 meter. Cara kerja pompa hydraulik ram automatic merupakan proses perubahan energi kinetis aliran air menjadi tekanan dinamik dan akibatnya menimbulkan palu air (water hammer) sehingga tekanan tinggi dalam pipa. Dengan mengusahakan supaya katub pembuang (waste valve) dan katub air keluar (delivery valve) terbuka dan tertutup secara bergantian, maka tekanan dinamik diteruskan sehingga tekanan inersia yang terjadi dalam pipa pemasukan memaksa air naik ke pipa penghisap (Utomo, 2015).

Pompa hydram menggunakan energi kinetik dari air yang mengalir di dalam pipa penggerak untuk memompa sekitar $10 \%$ dari air tersebut ke ketinggian yang lebih tinggi. Dengan demikian, tidak diperlukan masukan energi eksternal. Sudah banyak penelitian telah dilakukan membangun hydraulic ram dengan katup yang dibuat sendiri dan untuk pasokan air yang tinggi, tujuan dari penyelidikan ini adalah untuk membangun hydraulic ram yang dapat diandalkan dan murah, yang terbuat dari bagian-bagian yang tersedia secara lokal (Inthachot et al., 2015). Sistem hydraulic rum adalah sistem yang 
menggunakan energi kinetik dalam kolom air bergerak untuk mengangkat bagian dari air itu ke ketinggian yang lebih besar dari sumber suplai. Dengan tidak adanya penambahan energi eksternal, hidraulik yang dibuat dengan baik akan memompa sebagian air yang dipasok ke mana saja dari sekitar dua kali kepala pasokan sampai berkali-kali lipat pasokan, dengan efisiensi yang melebihi 65 persen atau bahkan 70 persen dalam beberapa rentang kapasitas dan tekanan (Wallace. 2007)

Sistem hydraulic ram adalah pompa air mekanis yang cocok digunakan untuk tujuan pertanian. Ini bisa menjadi pengganti yang baik untuk pompa air DC dalam penggunaan pertanian. Sistem pompa air ram hidrolik memiliki kemampuan untuk memompa air menggunakan energi gravitasi atau energi kinetik melalui sumber air yang mengalir. Proyek ini bertujuan untuk menganalisis dan mengembangkan pompa air ram untuk memenuhi head pengiriman yang diinginkan hingga ketinggian 3 meter dengan biaya operasi yang lebih sedikit. Desain terbaik mencapai target ketinggian $3 \mathrm{~m}$ dengan efisiensi $15 \%$ dan laju alir 11,82 I / mnt. Hasil dari penelitian ini menunjukkan bahwa semakin sedikit diameter ruang tekanan dan head pasokan yang lebih tinggi akan menciptakan tekanan yang lebih tinggi (Hussin et al., 2017).

Permasalahan yang dihadapi Kelompok Tani adalah kurangnya pengetahuan tentang teknologi tepat guna dalam membuat pompa yang dapat digunakan oleh petani Kelompok Tani dalam memenuhi kebutuhan air minum dan kegiatan aktifitas usataninya. Lokasi Kelompok Tani terletak di daerah yang hanya mengandalkan sumber air hujan pada saat musim hujan, sehingga petani sangat membutuhkan teknologi tepat guna dalam memenuhi kebutuhan air sepanjang tahun.

Kerangka pemecahan masalah yang perlu dilakukan adalah sebagai berikut:

1. Diperlukan teknologi tepat guna dalam rangka mengatasi permasalahan ketersediaan air didaerah perbukitan atau daerah datar tapi kesulitan memperoleh air, termasuk yang dihadapi oleh kelompok tani setiap tahunnya, berupa teknologi tepat guna pompa hydram (Hydraulic Ram Pump).

2. Diperlukan tindakan nyata guna memberikan pengetahuan kepada petani mitra cara membuat rancang bangun pompa hydram.

Penggunaan teknologi tepat guna pompa hydram adalah dalam rangka mengatasi permasalahan ketersediaan air sepanjang tahun bagi petani yang tidak mampu membeli pompa air bertenaga listrik di daerah pegunungan atau datar yang hanya memperoleh banyak air pada saat musim hujan.

\section{Target dan Capaian Luaran}

1) Memberi pengetahuan teknologi tepat guna pompa hydram.

2) Meningkatkan kemampuan petani dalam pemanfaatan pompa hydram, sehingga 
Muh. Ikbal Putera, Arman, dan Irmayani: Potensi Pompa Hydram (Hydraulic Ram Pump) Berteknologi Hydro Power Tanpa Listrik dan Ramah Lingkungan di Desa Nepo Kabupaten Barru.

dapat mengurangi biaya penggunaan energi listrik dengan penggunaan pompa hydram yang hemat energi dan ramah lingkungan.

3) Menjadi sumber pengetahuan dan dapat menjadi sumber mata pencaharian tambahan pendapatan bagi petani dengan memanfaatkan pompa hydram.

Manfaat dari program ini diharapkan dapat meningkatkan pengetahuan dan keterampilan kelompok tani dan petani lainnya dalam hal teknologi tepat guna pompa hydram yang hemat energi dan ramah lingkungan, sehingga akan mengurangi biaya penggunaan tenaga listrik.

Tahapan pengabdian:

- Survei lokasi pengabdian;

- Pelaksanaan kegiatan;

- Survei dan penempatan pompa bersama mitra dan masyarakat;

- Uji coba Pompa Hydram;

- Pemasangan dan operasional pompa;

- Bimbingan dan Sosialisasi Teknologi Pompa Hydram kepada Mitra dan Masyarakat.

\section{METODE PELAKSANAAN}

Metode yang digunakan dalam menerapkan dan mengaplikasikan teknologi tepat guna pompa hydram kepada Kelompok Tani dan masyarakat, mengggunakan metode survey kegiatan aktifitas pemasangan dan pengamatan lapangan, Participatory Rural Appraisal (PRA) yaitu melibatkan masyarakat dalam kegiatan. Pelaksanaan kegiatan ini dilaksanakan melalui: penyuluhan, pelatihan, demonstrasi, dan evaluasi untuk melihat efektivitas program sehingga program akan tersosialisasi dengan efektif dan efisien.

Uji coba dan pemasangan pompa hydram, berdasarkan bahwa pompa hydram memiliki mekanisme kerja melalui proses perubahan energi kinetis menjadi kecepatan aliran air dalam bentuk tekanan dinamis yang menghasilkan palu air (water hummer), sehingga menimbulkan tekanan yang tinggi di dalam pipa. Palu air terjadi berdasarkan air mengalir dari terjunan sumber air secara gravitasi dan menghantam arus balik sebagai debit air keluar katup buangan dan sisanya mendorong katup hisap mengalir ke dalam tabung udara sekaligus mendorong air dalam tabung udara keluar pipa keluar (pipe output). Energi yang timbul akibat hantaman yang berulang-ulang ini akan mengalirkan air ke areal yang lebih tinggi.

\section{HASIL DAN PEMBAHASAN}

\section{Hasil}

Tahapan awal kegiatan adalah survei lokasi kegiatan Teknologi Pompa Hydram di Desa Nepo Kecamatan Mallusetasi Kabupaten Barru. Kegiatan pengabdian ini dalam rangka penerapan teknologi sistem pompanisasi kepada masyarakat petani dengan menggunakan pompa yang tenaga penggeraknya adalah menggunkan tenaga air (hydro power) yang bebas polusi karena tidak menggunakan tenaga bahan bakar. Lokasi 
pengabdian ini berlokasi di Desa Nepo Kecamatan Mallusetasi Kabupaten Barru (Gambar 1). Survei lokasi pengabdian dalam rangka untuk mendapatkan lokasi sumber air di lokasi tersebut seperti sumber air arus sungai atau sumber mata air permukaan, hal ini dilaksanakan karena sumber air untuk menggerakkan pompa hydram. Karena pompa tersebut dapat beroperasi dengan menggunakan tenaga air (hydro power).

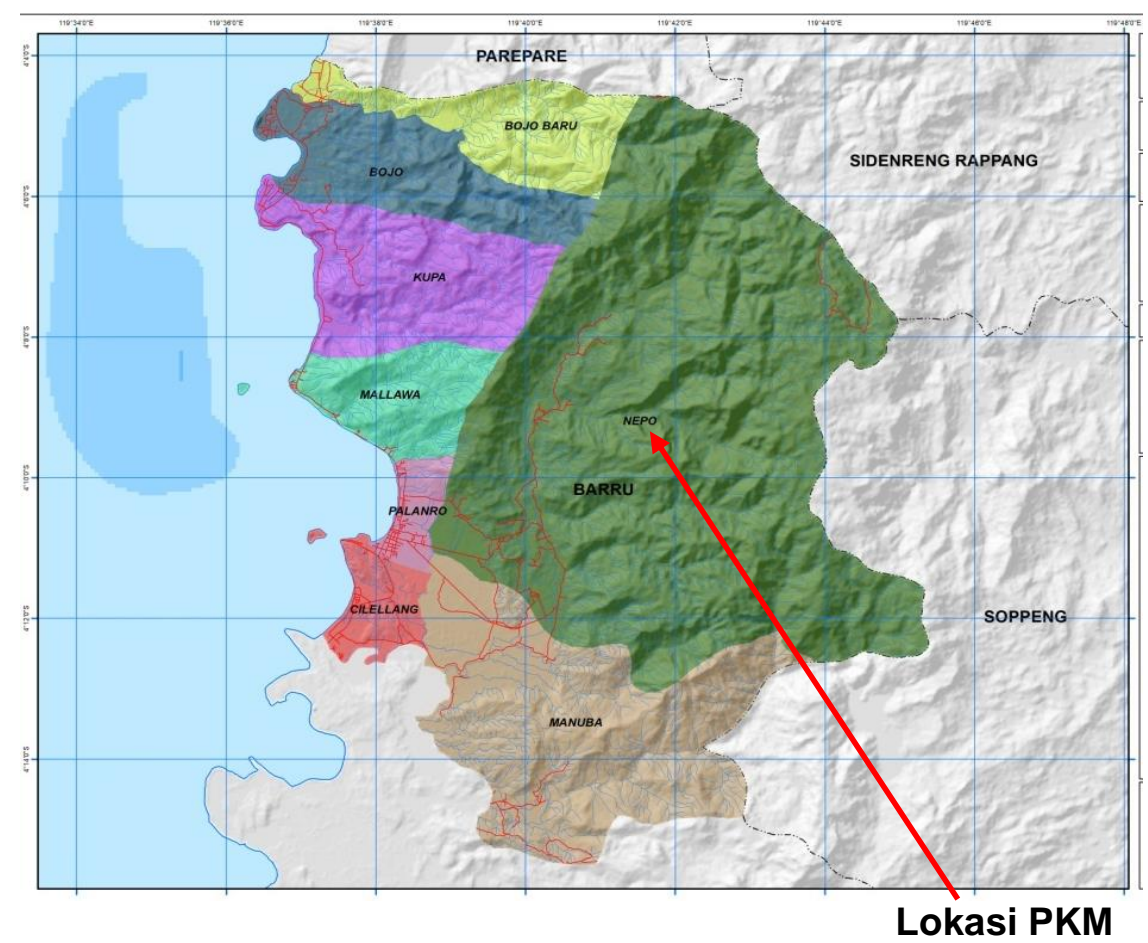

Gambar 1. Lokasi pengabdian PKM di Desa Nepo, Kecamatan Mattirotasi, Kabupaten Barru. Jarak dari Kampus UM-Parepare kurang lebih 60,7 Km.

Tahapan selanjutnya adalah penempatan pompa hydram tersebut dilokasi yang disepakati oleh masyarakat dan Kepala Desa Nepo. Di lokasi pengabdian terdapat lokasi yang memiliki bentuk topografi bergununggunung dan relatif curam, dengan demikian masalah air merupakan masalah yang tidak mudah diperoleh terutama pada saat kondisi musim kemarau. Sehingga untuk memperoleh air hanya dapat diperoleh dari menadah hujan yang terjadi pada saat 6 bulan musim hujan, atau memompa air yang terdapat di dalam sungai yang letaknya pada bagian bawah gunung. Dengan demikian permasalahan pemenuhan kebutuhan air bagi masyarakat desa yang tinggal di daerah berbukit dan bergunung adalah membutuhkan dana untuk membeli pompa air yang relative harganya mahal dan tersedia atau tidaknya sumber listrik untuk menggerakkan pompa dan mengangkat air dari dasar sungai.

\section{Penerapan teknologi.}

Pengadaan satu unit pompa hydram di lokasi pengabdian Desa Nepo, yang mana 
Muh. Ikbal Putera, Arman, dan Irmayani: Potensi Pompa Hydram (Hydraulic Ram Pump) Berteknologi Hydro Power Tanpa Listrik dan Ramah Lingkungan di Desa Nepo Kabupaten Barru.

merupakan salah satu pompa yang hemat energi dan ramah lingkungan. Pompa hydram merupakan bentuk teknologi tepat guna dalam bidang sistem pompanisasi dengan menggunakan tenaga momentum air (water hammer) untuk menaikkan air, dengan demikian pompa hydram merupakan salah satu pompa air yang tidak menggunakan BBM dan listrik.

Pompa hydram bekerja tanpa menggunakan bahan bakar atau energi dari luar. Pompa ini memanfaatkan tenaga aliran air yang jatuh dari ketinggian tempat pada suatu sumber, dan sebagian dari air tersebut dipompakan ke tempat yang lebih tinggi dengan sistim tekanan air. Menurut Utomo (2015), pada berbagai situasi, pompa hydram memiliki keuntungan dibandingkan dengan penggunaan pompa jenis lainnya, yaitu tidak membutuhkan bahan bakar atau tambahan tenaga dari sumber lain, tidak membutuhkan pelumasan, bentuknya sederhana, biaya pembuatannya serta pemeliharaannya tidak terlalu mahal dan tidak membutuhkan keterampilan teknik tinggi untuk membuatnya. Pompa ini bekerja dalam dua puluh empat jam per hari.

Survei dan rancangan pemasangan pompa hydram di lokasi pengabdian. Air adalah salah satu dari sekian banyak sumber daya alam yang sangat dibutuhkan bagi kehidupan mahkluk hidup, serta membantu aktivitas kehidupan manusia terutama dibidang pertanian yakni pengelolaan persawahan. Pompa hydram yang digunakan pada kegiatan pengabdian di Desa Nepo adalah pompa hydram buatan Bapak Susilo dari Jawa Tengah, sumber referensi ini berasal dari peneliti yang sudah pernah menggunakan produk beliau (Gambar 2).

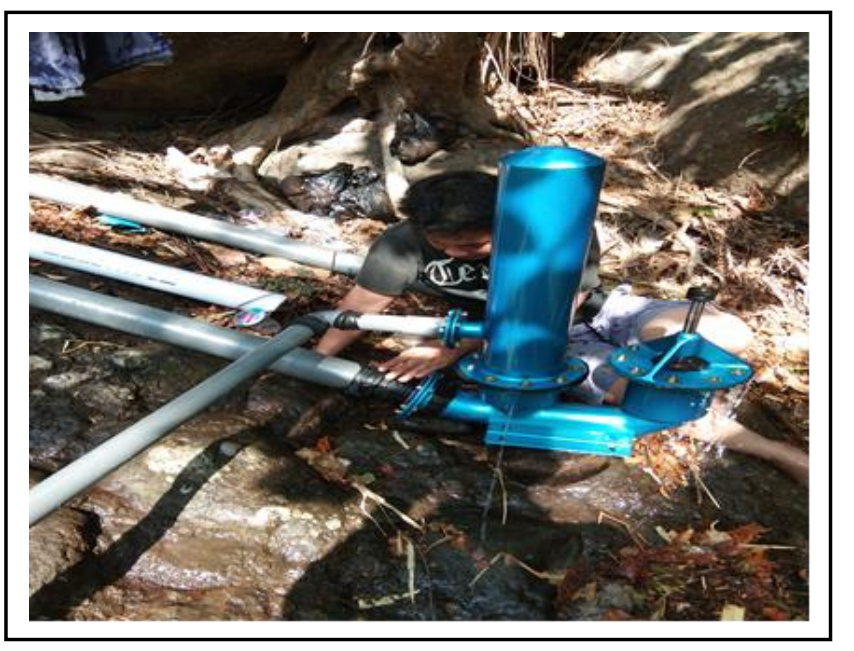

Gambar 2. Tipe pompa hydram.

Metode; survei untuk pemasangan vertikal dari sumber air sampai di pompa; 2. sebuah pompa hydram harus dilakukan dengan mempertimbangkan rancangannya. Daya angkat vertikal dari pompa sampai Beberapa hal perlu diketahui; 1. Tinggi jatuh tempat penampungan air; 3. Jumlah air yang tersedia untuk memberikan tenaga pada 
pompa (debit input $\left(Q_{\text {in }}\right)$ atau aliran masuk atau sumber); 4. Jumlah minimum air yang diperlukan setiap hari; 5. Panjang pipa pemasukan dari sumber air ke pompa; dan 6. Panjang pipa pengeluaran dari pompa ke tempat penampungan.

\section{Uji Coba Pompa Hydram}

Untuk mengetahui daya optimal pompa hydram perlu dilakukan survei lapangan untuk mendapatkan data-data yang menjadi parameter daya pompa. Beberapa data yang perlu didapatkan adalah:

a. Aliran sumber air; Data ini berupa debit sumber air yang ada pada kondisi normal dan pengukuran harus dilakukan pada musim kering karena pada saat itulah terjadi debit minimum.

b. Head air suplai; Ini dengan melihat sejauh mana ketinggian sumber air terhadap lokasi pompa hydram dan kemiringan lokasi di bawah sumber air.

c. Head penampung; Tinggi dari sumber air ke tempat yang diharapkan untuk suplai air perlu diketahui untuk memperkirakan penempatan pompa hydram.

d. Kebutuhan air; Ini diestimasi berdasarkan populasi penduduk atau luas lahan pertanian yang akan dilayani atau kebutuhan lainnya sesuai dengan kondisi tiap tiap daerah.

Setelah survey dilaksanakan dengan melihat ketinggian lokasi di daerah tersebut, dilakukan uji coba di lokasi kegiatan Pengabdian Masyarakat di Desa Nepo Kabupaten Barru sebelum pemasangan di lapangan. Hasil uji coba pompa hydram dapat mengalirkan air sampai dengan ketinggian kurang lebih 10 meter. Hal ini sudah melebihi hasil survey dengan ketinggian 7 meter. Setelah observasi lapangan dan diperoleh data tentang kondisi lapangan dan lingkungan pelaksanaan kegiatan pengabdian masyarakat (Gambar 3).

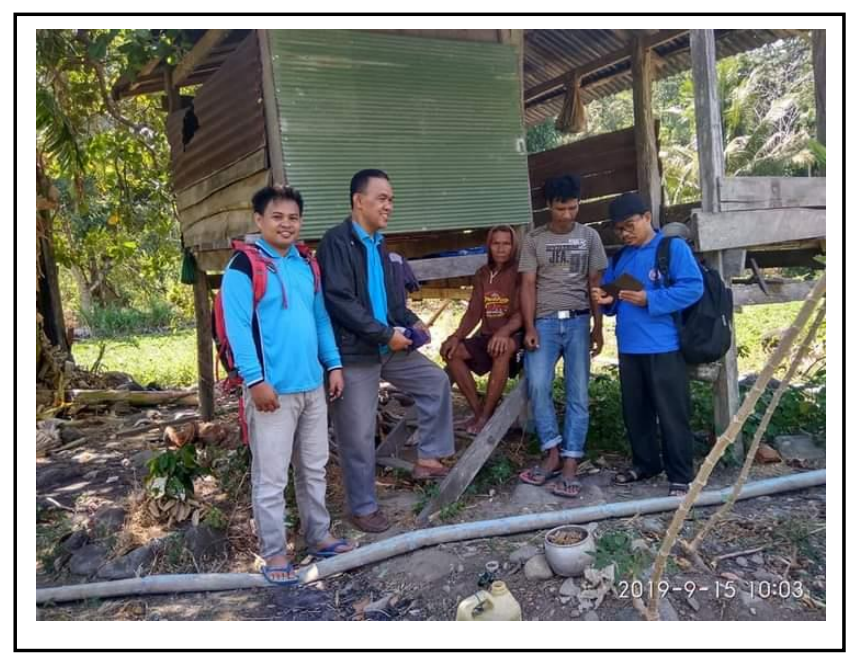

Gambar 3. Sosialisasi teknologi dan pemasangan pompa hydram. 
Muh. Ikbal Putera, Arman, dan Irmayani: Potensi Pompa Hydram (Hydraulic Ram Pump) Berteknologi Hydro Power Tanpa Listrik dan Ramah Lingkungan di Desa Nepo Kabupaten Barru.

Tahap selanjutnya adalah memasang secara permanen pompa hydram di Desa Nepo Kabupaten Barru sebagai pompa harapan masyarakat (Gambar 4). Untuk mengetahui daya pompa yang aktif bergerak sendiri, diperlukan mekanisme buka-tutup aliran air secara otomatis bekerja, yaitu dengan mengandalkan katup buang. Saat katup buang tertutup akibat tekanan atau dorongan air maka air akan kembali dan akan terjadi water hammer (hantaman air).
Akibat air mengalir di katup mengalir kembali maka tekanan pada tutup berkurang dan karena kekuatan dorongan pegas sehingga katup bergerak turun dan membuka. Setelah terbentuk water hammer serta katup buang terbuka, air akan kembali mengalir ke katup buang. Ketika terjadi gerakan menutup, check valve berperan pada tambahan tekanan air yang mengalir kearah katup buang (Gambar 5).

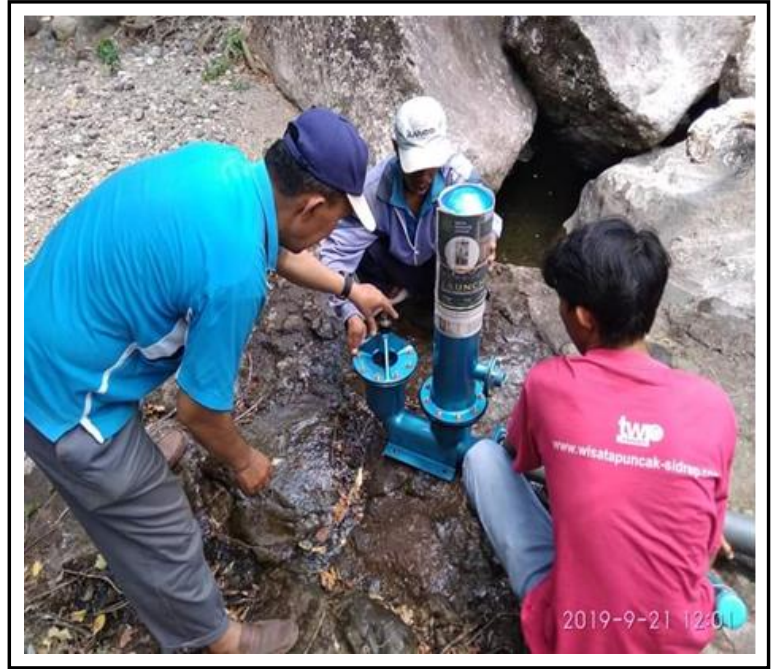

Gambar 4. Petunjuk teknis pemasangan pompa hydram.

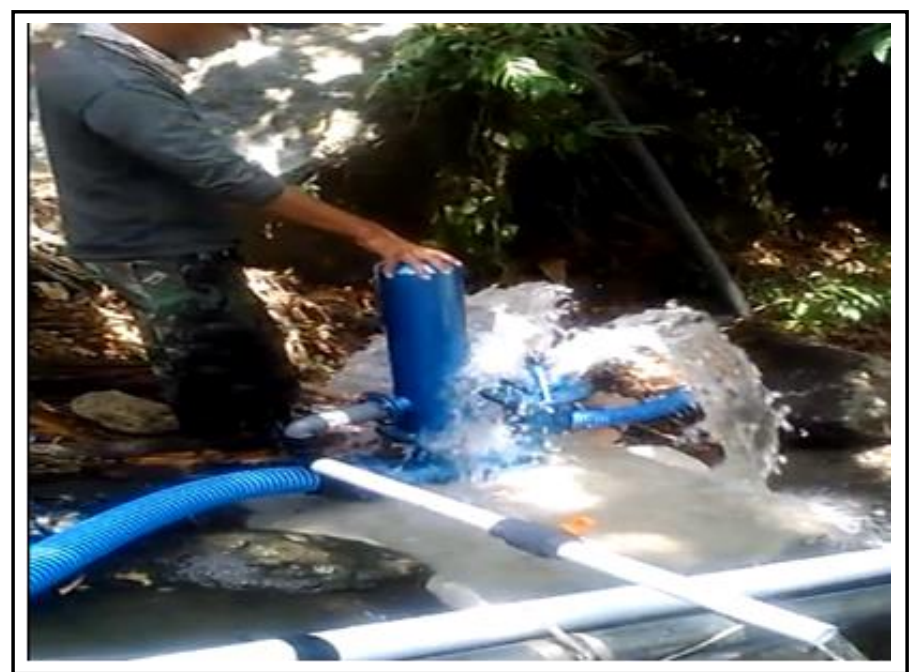

Gambar 5. Pompa hydram sedang beroperasi. 


\section{Pembahasan}

Berdasarkan hasil survey, dan uji coba lapangan dan penentuan tempat penempatan pompa hydram diperoleh data potensinya yaitu tinggi jatuh air atau head sumber sebesar $2,5 \mathrm{~m}$, jarak antara sumber air dan peletakkan pompa hydram sebesar $30 \mathrm{~m}$ dan ketinggian pemompaan yang dibutuhkan sehingga dapat mengairi; kebun, dan persawahan yaitu kurang lebih setinggi $10 \mathrm{~m}$ dengan jarak pompa ke kebun serta persawahan masyarakat $50 \mathrm{~m}$.

Namun pada saat ini, kondisi di lokasi pengabdian juga masuk pada kondisi musim kemarau, yang mengakibatkan debit air pada saluran/arus sungai tersebut menurun. Dengan demikian pada saat ini, operasional pompa hydram tersebut digerakkan oleh sumber mata air yang mengalir dari sungai tersebut, berasal dari mata air di saluran sungai desa Nepo, dengan debit 2 liter/detik pada saat musim kemarau saat ini. Air inilah yang dipompa masuk kedalam bak penampungan, selanjutnya dialirkan ke areal atau lahan pertanian petani. Optimalisasi pompa hydram oleh petani dapat dilaksanakan dengan tetap memperhatikan beberapa aspek; menurut Panly (2016), pada awal proses penempatan pompa hydram, terlebih dahulu kita perlu melakukan survey di lokasi pemasangan pompa. Setelah menentukan lokasi yang tepat untuk pembuatan pompa hydram maka data-data yang diperlukan dapat dicari. Data yang perlu dicari pada saat melakukan survey lokasi adalah 1). Potensi dari sumber air antara lain tinggi jatuh air atau head sumber dan ketersediaan debit air yang cukup untuk menjaga kelangsungan proses pemompaan; 2). Jarak dari sumber air dengan lokasi tempat dimana dari jarak tersebut akan menentukan untuk panjang pipa suplai; 3). Ketinggian pemompaan yang perlukan.

\section{SIMPULAN}

- Daya optimal pompa hydram diperoleh dari tenaga air (hydro power) berdasarkan kecepatan, tekanan dan posisi ketinggian pipa masuk air masuk kedalam pompa. Tenaga air (water hammer) inilah yang menggerakkan mekanisme di dalam pompa.

- Optimalisasi pompa hydram mendapatkan energi potensial dari hantaman air dengan syarat utama yaitu harus ada terjunan air yang dialirkan melalui pipa dengan beda tinggi elevasi dengan pompa hydram minimal 1 meter.

- Hasil uji coba pompa hydram dengan daya optimal dapat mengalirkan air (debit keluaran / $Q_{\text {out }}$ ) dengan ketinggian kurang lebih 10 meter. Debit aliran pada musim kemarau pada pipa keluaran di kolam penampungan untuk air minum masyarakat adalah $2 \mathrm{lt} / \mathrm{dt}$, dan debit keluaran pada pipa untuk kebun masyarakat adalah 0,33 lt/dt. 
Muh. Ikbal Putera, Arman, dan Irmayani: Potensi Pompa Hydram (Hydraulic Ram Pump) Berteknologi Hydro Power Tanpa Listrik dan Ramah Lingkungan di Desa Nepo Kabupaten Barru.

- Pada saat musim kemarau, untuk menggerakkan pompa hydram dapat dilaksanakan dengan mencari sumber mata air jika sumber air dari sungai dan sumur kekurangan air (debit input) berkurang. Perlunya pelestarian lahan (tanah, hutan dan air) dalam rangka menjaga sumber air sepanjang tahun.

\section{UCAPAN TERIMA KASIH}

Penulis mengucapkan terima kasih kepada Dirjen Dikti. Kementerian Riset, Teknologi dan Pendidikan Tinggi yang telah membiayai kegiatan Program Kemitraan Masyarakat (PKM) ini, terimakasih juga kepada Kopertis Wilayah IX Sulawesi, Rektor UM-Parepare, LPPM UM-Parepare beserta dosen, anggota tim yang membantu dan semua pihak yang membantu pelaksanaan kegiatan ini.

\section{DAFTAR PUSTAKA}

Ahmadi S., 2013, Pengaruh variasi tinggi keluaran tabung kompresor (air chamber) terhadap efisiensi pompa hydram (hydraulicram Pump ), Tugas
Akhir, Teknik Mesin, Universitas Mataram.

Dinar M. F., Hari A. C. W., Latifah N. Q., Enjang, J. M., 2013, Uji efisiensi pompa hydram dengan variasi volume tabung udara, Prosiding Seminar Nasional Kontribusi Fisika, Bandung, 2-3 Desember.

Direktorat Pengelolaan Air, 2009, Pedoman teknis pengembangan irigasi pompa hydram, Direktorat Jenderal Pengelolaan Lahan dan Air, Departemen Pertanian Republik Indonesia.

Panly M. E. L 2016. Skripsi. Rancang Bangun Pompa Hydram (Hydraulic RamPump) Untuk Model Sistim Irigasi Persawahan Masyarakat Di Desa Wonokarto Kecamatan Gadingrejo Kabupaten Pringsewu Provinsi Lampung.

Sularso. 2004. Pompa dan Komperesor : Pemilihan, Pemakaian dan Pemeliharaan. Bandung: PT Pradnya Paramita.

Utomo Prijo Gatut, Supardi, Santoso Edi, 2015. Analisa Pengaruh Tinggi Jatuhan Air Terhadap Head Pompa Hydram. Jurnal Pengabdian LPPM UNTAG Surabaya Nopember 2015, Vol. 01, No. 02, Hal $211-224$. 